\title{
Salinimicrobium gaetbulicola sp. nov., isolated from tidal flat sediment
}

Correspondence

Jung-Hoon Yoon

jhyoon69@skku.edu
The genus Salinimicrobium, a member of the family Flavobacteriaceae of the phylum 'Bacteroidetes' (Bernardet \& Nakagawa, 2006), was proposed by Lim et al. (2008) by the reclassification of Salegentibacter catena (Ying et al., 2007) as Salinimicrobium catena and by the description of one novel species, Salinimicrobium xinjiangense. Subsequently, two further Salinimicrobium species, Salinimicrobium terrae (Chen et al., 2008) and Salinimicrobium marinum (Nedashkovskaya et al., 2010) were described. Members of the genus Salinimicrobium have been isolated from marine sediments and soils of salt lakes (Chen et al., 2008; Lim et al., 2008; Nedashkovskaya et al., 2010). In this study, we report the taxonomic characterization of a Salinimicrobium-like bacterial strain, BB-My $20^{\mathrm{T}}$, which was isolated from tidal flat sediment from Beolgyo on the southern coast of Korea.

Abbreviation: CMC, carboxymethyl-cellulose.

The GenBank/EMBL/DDBJ accession number for the $16 \mathrm{~S}$ rRNA gene sequence of strain BB-My20 ${ }^{\top}$ is JF340052.

A supplementary figure is available with the online version of this paper.
The dilution plating technique was used for the isolation of bacterial strains from tidal flat sediment samples. Strain $\mathrm{BB}-\mathrm{My} 20^{\mathrm{T}}$ was isolated on marine agar 2216 (MA; Difco) at $25{ }^{\circ} \mathrm{C}$ and cultivated routinely on MA at $37{ }^{\circ} \mathrm{C}$. S. catena JCM $14015^{\mathrm{T}}\left(=\mathrm{HY}^{\mathrm{T}}\right)$, S. xinjiangense KCTC $12883^{\mathrm{T}}, \mathrm{S}$. terrae DSM $17865^{\mathrm{T}}$ and S. marinum LMG $25395^{\mathrm{T}}$ were used as reference strains for DNA-DNA hybridization, fatty acid analysis and other phenotypic tests. S. catena JCM $14015^{\mathrm{T}}$ was also used for polar lipid analysis. Cell morphology was examined by using light microscopy (E600; Nikon) and transmission electron microscopy (CM20; Philips). The latter technique was also used to assess the presence of flagella on cells from an exponentially growing culture on MA. For this purpose, cells were negatively stained with $1 \%(\mathrm{w} / \mathrm{v})$ phosphotungstic acid and the grids were examined after being air-dried. Gliding motility was investigated as described by Bowman (2000). The Gram reaction was determined by using the bioMérieux Gram stain kit according to the manufacturer's instructions. Growth at $4,10,15,20,25,30,35,37,40$ and $45^{\circ} \mathrm{C}$ was investigated on MA. The $\mathrm{pH}$ range for growth was 
Table 1. Differential phenotypic characteristics of Salinimicrobium gaetbulicola sp. nov. $\mathrm{BB}-\mathrm{My}_{2} \mathrm{O}^{\top}$ and the type strains of other members of the genus Salinimicrobium

Strains: 1, S. gaetbulicola sp. nov. BB-My20 ${ }^{\mathrm{T}} ; 2$, S. catena JCM $14015^{\mathrm{T}}$; 3, S. xinjiangense KCTC $12883^{\mathrm{T}}$; 4, S. terrae DSM $17865^{\mathrm{T}}$; 5, S. marinum LMG $25395^{\mathrm{T}}$. Data were taken from this study unless indicated otherwise. +, Positive reaction; -, negative reaction; $\mathrm{w}$, weakly positive reaction. All strains are positive for the following: catalase; hydrolysis of aesculin, casein, DNA, starch (weak for $S$. marinum LMG 25395 ${ }^{\mathrm{T}}$ ), and Tweens 20, 40, 60 and 80 (weak for $S$. marinum LMG $25395^{\mathrm{T}}$ ); acid production from cellobiose, D-glucose (weak for S. catena JCM $14015^{\mathrm{T}}$ ) and maltose; susceptibility to carbenicillin, cephalothin, chloramphenicol, lincomycin, novobiocin, oleandomycin and tetracycline (weak for S. gaetbulicola BB-My $20^{\mathrm{T}}, S$. xinjiangense KCTC $12883^{\mathrm{T}}$, S. terrae DSM $17865^{\mathrm{T}}$ and S. marinum LMG $25395^{\mathrm{T}}$ ); and activity of alkaline phosphatase, esterase (C4) (weak for S. marinum LMG $25395^{\mathrm{T}}$ ), esterase lipase (C8), leucine arylamidase, valine arylamidase, naphthol-AS-BI-phosphohydrolase (weak for S. catena JCM $14015^{\mathrm{T}}$ and S. xinjiangense KCTC $12883^{\mathrm{T}}$ ) and $\alpha$-glucosidase. All strains are negative for the following: Gramstaining; $\mathrm{H}_{2} \mathrm{~S}$ and indole production; hydrolysis of CMC, hypoxanthine, urea and xanthine; acid production from myo-inositol, D-mannitol, L-rhamnose and D-sorbitol; susceptibility to ampicillin, gentamicin, kanamycin, neomycin, penicillin G, polymyxin B and streptomycin; and activity of arginine dihydrolase, lysine decarboxylase, ornithine decarboxylase, lipase (C14), $\alpha$-galactosidase, $\beta$ galactosidase, $\alpha$-mannosidase and $\alpha$-fucosidase.

\begin{tabular}{|c|c|c|c|c|c|}
\hline Characteristic & 1 & 2 & 3 & 4 & 5 \\
\hline Oxidase & - & - & + & + & + \\
\hline Nitrate reduction & - & - & - & + & + \\
\hline \multicolumn{6}{|l|}{ Hydrolysis of: } \\
\hline Gelatin & + & + & - & - & - \\
\hline L-Tyrosine & + & - & + & + & + \\
\hline \multicolumn{6}{|l|}{ Acid production from: } \\
\hline L-Arabinose & W & - & - & $\mathrm{W}$ & + \\
\hline D-Fructose & + & - & - & - & + \\
\hline D-Galactose & - & $\mathrm{W}$ & + & + & + \\
\hline Lactose & - & + & + & + & + \\
\hline D-Mannose & - & - & w & + & + \\
\hline Melezitose & - & - & + & - & - \\
\hline Melibiose & - & - & - & - & + \\
\hline Raffinose & - & - & - & - & + \\
\hline D-Ribose & + & - & - & - & - \\
\hline Sucrose & - & - & + & - & + \\
\hline Trehalose & + & - & + & + & + \\
\hline D-Xylose & $\mathrm{w}$ & - & $\mathrm{W}$ & $\mathrm{w}$ & + \\
\hline \multicolumn{6}{|c|}{ Enzyme activity (API ZYM) } \\
\hline Cystine arylamidase & - & $\mathrm{W}$ & $\mathrm{W}$ & + & $\mathrm{W}$ \\
\hline Trypsin & $\mathrm{w}$ & + & - & - & - \\
\hline$\alpha$-Chymotrypsin & + & $\mathrm{W}$ & + & + & - \\
\hline Acid phosphatase & + & - & + & + & + \\
\hline$\beta$-Glucuronidase & - & - & + & - & - \\
\hline$\beta$-Glucosidase & $\mathrm{w}$ & - & - & + & + \\
\hline $\begin{array}{l}N \text {-Acetyl- } \beta \text { - } \\
\text { glucosaminidase }\end{array}$ & + & - & + & + & + \\
\hline
\end{tabular}

Table 1. cont.

\begin{tabular}{|lccccc|}
\hline Characteristic & $\mathbf{1}$ & $\mathbf{2}$ & $\mathbf{3}$ & $\mathbf{4}$ & $\mathbf{5}$ \\
\hline $\begin{array}{c}\text { DNA G+C content } \\
(\mathrm{mol} \%)\end{array}$ & 45.1 & $44.4^{\star}$ & $42.1^{\star}$ & $42.8^{\star}$ & $40.9^{\star}$ \\
\hline
\end{tabular}

${ }^{\star}$ Data taken from: Ying et al. (2007); Chen et al. (2008); Lim et al. (2008); and Nedashkovskaya et al. (2010).

determined in marine broth 2216 (MB; Difco) adjusted to $\mathrm{pH}$ 5.0-10.0 (in increments of $0.5 \mathrm{pH}$ unit) by using sodium acetate/acetic acid and $\mathrm{Na}_{2} \mathrm{CO}_{3}$ buffers; $\mathrm{pH}$ values were verified after autoclaving. Growth in the absence of $\mathrm{NaCl}$ and in the presence of $0.5,1.0,2.0$ and $3.0 \%(\mathrm{w} / \mathrm{v}) \mathrm{NaCl}$ was investigated in trypticase soy broth prepared according to the formula of the Difco medium except that $\mathrm{NaCl}$ was excluded and $0.45 \%(\mathrm{w} / \mathrm{v}) \mathrm{MgCl}_{2} \cdot 6 \mathrm{H}_{2} \mathrm{O}$ was added. Growth in the presence of $2.0-11.0 \%(\mathrm{w} / \mathrm{v}) \mathrm{NaCl}$ (final concentrations; in increments of $1.0 \%$ ) was investigated in MB. Growth under anaerobic conditions was determined after incubation in an anaerobic chamber (1029; Forma, $\mathrm{N}_{2} / \mathrm{CO}_{2} / \mathrm{H}_{2}, 86: 7: 7$ ) on $\mathrm{MA}$ and on MA supplemented with potassium nitrate $(0.1 \%, w / v)$, both of which had been prepared anaerobically under a nitrogen atmosphere. Catalase and oxidase activities were determined as described by Cowan \& Steel (1965). Hydrolysis of aesculin, urea, gelatin and Tweens (20, 40, 60 and 80 ) and reduction of nitrate were determined as described previously (Lányí, 1987) with the modification that artificial seawater was used for preparation of media. The artificial seawater contained $\left(\mathrm{l}^{-1}\right.$ distilled water $)$ $23.6 \mathrm{~g} \mathrm{NaCl}, 0.64 \mathrm{~g} \mathrm{KCl}, 4.53 \mathrm{~g} \mathrm{MgCl}_{2} .6 \mathrm{H}_{2} \mathrm{O}, 5.94 \mathrm{~g}$ $\mathrm{MgSO}_{4} \cdot 7 \mathrm{H}_{2} \mathrm{O}$ and $1.3 \mathrm{~g} \mathrm{CaCl}_{2} \cdot 2 \mathrm{H}_{2} \mathrm{O}$ (Bruns et al., 2001). Hydrolysis of casein, hypoxanthine, starch, L-tyrosine and xanthine was tested on MA using the substrate concentrations described previously (Cowan \& Steel, 1965). Hydrolysis of carboxymethyl-cellulose (CMC) was investigated on MA containing $0.5 \%(\mathrm{w} / \mathrm{v})$ CMC (Sigma) and detected according to the method of Teather \& Wood (1982). DNase activity was examined by using DNase test agar with methyl green (Difco) with the modification that artificial seawater was used for the preparation of the medium. Acid production from carbohydrates was tested as described by Leifson (1963). Susceptibility to antibiotics was investigated on MA by using antibiotic discs (Advantec) containing the following ( $\mu \mathrm{g}$, except where marked): ampicillin (10), carbenicillin (100), cephalothin (30), chloramphenicol (100), gentamicin (30), kanamycin (30), lincomycin (15), neomycin (30), novobiocin (5), oleandomycin (15), penicillin G (20 U), polymyxin B (100 U), streptomycin (50) and tetracycline (30). Enzyme activities and additional biochemical tests were performed by using the API ZYM and 20E systems (bioMérieux) incubated at $37^{\circ} \mathrm{C}$ for $8 \mathrm{~h}$ and 3 days, respectively, according to the instructions of the manufacturer. Morphological, cultural, physiological and biochemical properties of strain $\mathrm{BB}-\mathrm{My} 20^{\mathrm{T}}$ are given in the species description and in Table 1. 
Cell biomass of strain BB-My $20^{\mathrm{T}}$ for DNA extraction and for the analyses of isoprenoid quinones and polar lipids was obtained from cultures grown for 3 days in $\mathrm{MB}$ at $30{ }^{\circ} \mathrm{C}$. Cell biomass of S. catena JCM $14015^{\mathrm{T}}$ for DNA extraction and polar lipid analysis was obtained from cultures grown for 3 days in $\mathrm{MB}$ at $30{ }^{\circ} \mathrm{C}$. Chromosomal DNA was extracted and purified according to the method described by Yoon et al. (1996), with the exception that RNase T1 was used in combination with RNase A to minimize contamination of RNA. The $16 \mathrm{~S}$ rRNA gene was amplified using PCR with two universal primers (5'GAGTTTGATCCTGGCTCAG- $3^{\prime}$ and $5^{\prime}$-AGAAAGGAGGTGATCCAGCC-3') as described previously (Yoon et al., 1998) and purified by using a QIAquick purification kit (Qiagen). Sequencing of the amplified 16S rRNA gene and phylogenetic analysis were performed as described by Yoon et al. (2003). The almost complete 16S rRNA gene sequence of strain BB-My20 ${ }^{\mathrm{T}}$, comprising $1448 \mathrm{nt}$ (representing approximately $96 \%$ of the Escherichia coli $16 \mathrm{~S}$ rRNA gene sequence), was determined in this study. In the neighbour-joining phylogenetic tree based on 16S rRNA gene sequences, strain $\mathrm{BB}-\mathrm{My} 20^{\mathrm{T}}$ fell within the clade comprising the type strains of species of the genus Salinimicrobium, joining S. catena $\mathrm{HY}^{\mathrm{T}}$ with a bootstrap resampling value of $88.8 \%$ (Fig. 1). Clustering of strain $\mathrm{BB}-\mathrm{My} 20^{\mathrm{T}}$ and the type strains of species of the genus Salinimicrobium was also observed in trees reconstructed using the maximum-likelihood and maximum-parsimony algorithms (not shown). Strain BB-My $20^{\mathrm{T}}$ exhibited $16 \mathrm{~S}$ rRNA gene sequence similarity values of $97.4 \%$ to $S$. catena $\mathrm{HY}^{\mathrm{T}}, 95.4-96.9 \%$ to the type strains of the other
Salinimicrobium species and less than $94.4 \%$ to strains of the other species used in the phylogenetic analysis.

Isoprenoid quinones were analysed according to the method of Komagata \& Suzuki (1987) and analysed using reversed-phase HPLC and a YMC ODS-A $(250 \times 4.6 \mathrm{~mm})$ column. The predominant isoprenoid quinone detected in strain BB-My20 ${ }^{\mathrm{T}}$ was menaquinone-6 (MK-6), which is in line with that found in other members of the genus Salinimicrobium (Chen et al., 2008; Lim et al., 2008; Nedashkovskaya et al., 2010) and all other members of the family Flavobacteriaceae (Bernardet \& Nakagawa, 2006). For cellular fatty acid analysis, cell mass of strain BBMy $20^{\mathrm{T}}$ and the type strains of the four recognized species of the genus Salinimicrobium was harvested from MA plates after cultivation for 3 days at $30{ }^{\circ} \mathrm{C}$. Fatty acids were saponified, methylated and extracted using the standard protocol of the MIDI (Sherlock Microbial Identification System, version 4.0). The mixture of fatty acids was separated by GC (Hewlett Packard 6890) and identified by using the TSBA40 database of the Microbial Identification System (Sasser, 1990). The complete cellular fatty acid profiles of strain BB-My $20^{\mathrm{T}}$ and of type strains of species of the genus Salinimicrobium grown and analysed under identical conditions in this study are compared in Table 2. The major fatty acids ( $>10 \%$ of the total fatty acids) found in strain BB-My20 ${ }^{\mathrm{T}}$ were iso- $\mathrm{C}_{15: 0}(24.0 \%)$, anteiso- $\mathrm{C}_{15: 0}$ $(11.8 \%)$ and iso- $\mathrm{C}_{17: 0} 3-\mathrm{OH}(11.3 \%)$. The fatty acid profiles of the five strains were essentially similar, even though there were differences in the proportions of some fatty acids (Table 2). Polar lipids were extracted according to

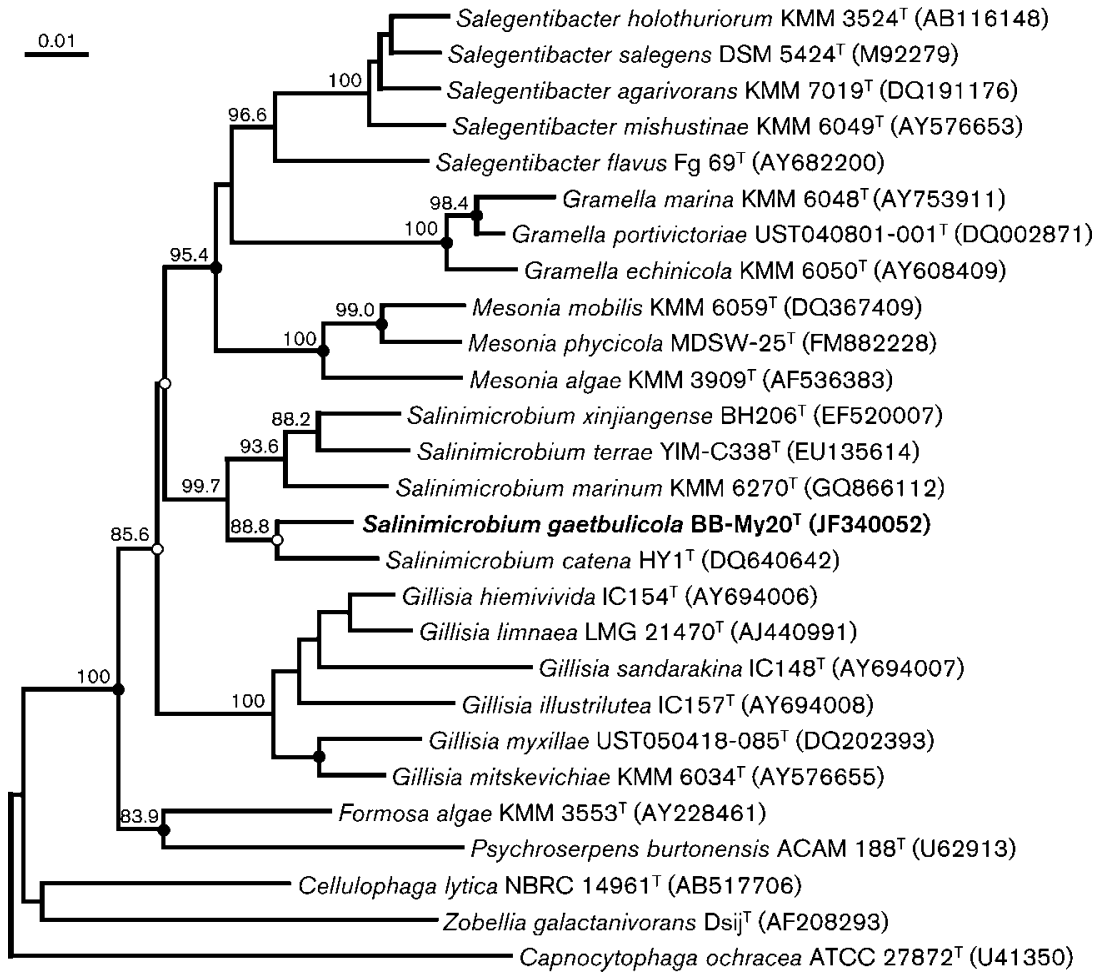

Fig. 1. Neighbour-joining phylogenetic tree based on 16S rRNA gene sequences showing the positions of Salinimicrobium gaetbulicola BB-My $20^{\top}$, strains of other Salinimicrobium species and representatives of some other related taxa. Only bootstrap values (expressed as percentages of 1000 replications) greater than $70 \%$ are shown at branching points. Filled circles indicate that the corresponding nodes were also recovered in trees generated with the maximum-likelihood and maximumparsimony algorithms; open circles indicate that the corresponding nodes were also recovered in trees generated with the maximum-likelihood algorithm. Capnocytophaga ochracea ATCC $27872^{\top}$ (GenBank accession no. U41350) was used as an outgroup. Bar, 0.01 substitutions per nucleotide position. 
Table 2. Cellular fatty acid compositions (\%) of Salinimicrobium gaetbulicola sp. nov. BB-My20 ${ }^{\top}$ and the type strains of other Salinimicrobium species

Strains: 1, S. gaetbulicola sp. nov. BB-My20 ${ }^{\mathrm{T}} ; 2$, S. catena JCM $14015^{\mathrm{T}}$; 3, S. xinjiangense KCTC $12883^{\mathrm{T}} ; 4$, S. terrae DSM $17865^{\mathrm{T}} ; 5, S$. marinum LMG $25395^{\mathrm{T}}$. All data are from this study and all strains were grown for 3 days on MA at $30{ }^{\circ} \mathrm{C}$. Fatty acids that represented $<1.0 \%$ in all strains were omitted. tr, Trace $(<0.5 \%)$; - not detected.

\begin{tabular}{|c|c|c|c|c|c|}
\hline Fatty acid & 1 & 2 & 3 & 4 & 5 \\
\hline \multicolumn{6}{|l|}{ Straight-chain } \\
\hline $\mathrm{C}_{15: 0}$ & 3.3 & 3.3 & 4.9 & 2.4 & 9.4 \\
\hline \multicolumn{6}{|l|}{ Branched } \\
\hline iso- $\mathrm{C}_{13: 0}$ & 1.3 & 0.6 & $\operatorname{tr}$ & - & $\operatorname{tr}$ \\
\hline iso- $\mathrm{C}_{14: 0}$ & 0.8 & 3.3 & 1.2 & 2.2 & 1.4 \\
\hline iso- $\mathrm{C}_{15: 0}$ & 24.0 & 17.6 & 12.7 & 13.3 & 20.9 \\
\hline iso- $\mathrm{C}_{15: 1} \mathrm{G}^{*}$ & 6.0 & 2.9 & 1.1 & 5.2 & 4.0 \\
\hline anteiso- $\mathrm{C}_{15: 0}$ & 11.8 & 6.1 & 8.6 & 20.2 & 8.0 \\
\hline anteiso- $\mathrm{C}_{15: 1} \mathrm{~A}^{*}$ & - & $\operatorname{tr}$ & - & 3.5 & $\operatorname{tr}$ \\
\hline iso- $\mathrm{C}_{16: 0}$ & 3.6 & 19.2 & 11.1 & 9.9 & 5.8 \\
\hline iso- $\mathrm{C}_{16: 1} \mathrm{H}^{*}$ & 1.5 & 5.6 & 1.8 & 3.7 & 1.7 \\
\hline iso- $\mathrm{C}_{17: 0}$ & $\operatorname{tr}$ & - & 1.2 & - & $\operatorname{tr}$ \\
\hline \multicolumn{6}{|l|}{ Unsaturated } \\
\hline $\mathrm{C}_{15: 1} \omega 6 c$ & 1.2 & 1.3 & 0.6 & 1.2 & 2.9 \\
\hline $\mathrm{C}_{17: 1} \omega 6 c$ & 1.1 & 2.4 & 1.8 & 0.9 & 1.7 \\
\hline $\mathrm{C}_{17: 1} \omega 8 c$ & - & $\operatorname{tr}$ & 1.0 & - & 1.3 \\
\hline iso- $\mathrm{C}_{17: 1} \omega 9 c$ & 7.3 & 3.8 & 6.0 & 2.4 & 3.5 \\
\hline anteiso- $\mathrm{C}_{17: 1} \omega 9 c$ & 2.9 & 1.9 & 3.6 & 4.3 & - \\
\hline \multicolumn{6}{|l|}{ Hydroxy } \\
\hline $\mathrm{C}_{15: 0} 2-\mathrm{OH}$ & 2.5 & 1.1 & 1.9 & 2.5 & 2.2 \\
\hline $\mathrm{C}_{15: 0} 3-\mathrm{OH}$ & - & - & - & - & 2.1 \\
\hline iso- $\mathrm{C}_{15: 0} 3-\mathrm{OH}$ & 3.9 & 2.3 & 1.9 & 1.5 & 2.6 \\
\hline iso- $\mathrm{C}_{16: 0} 3-\mathrm{OH}$ & 2.7 & 4.9 & 5.4 & 5.9 & 4.5 \\
\hline $\mathrm{C}_{17: 0} 2-\mathrm{OH}$ & 4.0 & 2.2 & 8.7 & 9.7 & 3.3 \\
\hline $\mathrm{C}_{17: 0} 3-\mathrm{OH}$ & - & - & 1.3 & - & 1.0 \\
\hline iso- $\mathrm{C}_{17: 0} 3-\mathrm{OH}$ & 11.3 & 7.4 & 14.0 & 5.0 & 12.1 \\
\hline 10-Methyl $\mathrm{C}_{18: 0}$ (TBSA) & - & - & $\operatorname{tr}$ & $\operatorname{tr}$ & 1.1 \\
\hline Summed feature $3 \dagger$ & 4.0 & 7.6 & 4.1 & 2.8 & 5.6 \\
\hline \multicolumn{6}{|l|}{ Unknown $\ddagger$} \\
\hline ECL 13.565 & 2.9 & 2.2 & 2.4 & 0.4 & 1.0 \\
\hline ECL 16.582 & 0.8 & $\operatorname{tr}$ & 0.8 & $\operatorname{tr}$ & 1.3 \\
\hline
\end{tabular}

${ }^{\star}$ Double bond position indicated by a capital letter is unknown. $\dagger$ Summed features represent groups of two or three fatty acids that could not be separated by GLC with the MIDI system. Summed feature 3 contained $\mathrm{C}_{16: 1} \omega 7 c$ and/or iso- $\mathrm{C}_{15: 0} 2-\mathrm{OH}$. $\ddagger \mathrm{ECL}$, Equivalent chain-length.

the procedures described by Minnikin et al. (1984) and identified by two-dimensional TLC followed by spraying with appropriate detection reagents (Minnikin et al., 1984; Komagata \& Suzuki, 1987). The polar lipid profiles of strain $\mathrm{BB}-\mathrm{My} 20^{\mathrm{T}}$ and the type strain of $S$. catena, the type species of the genus, were highly similar in that the major polar lipids were phosphatidylethanolamine and one unidentified lipid (Fig. S1, available in IJSEM Online). The DNA G + C content was determined by the method of Tamaoka \& Komagata (1984) with the modification that DNA was hydrolysed and the resultant nucleotides were analysed by reversed-phase HPLC equipped with a YMC ODS-A $(250 \times 4.6 \mathrm{~mm})$ column. The nucleotides were eluted with a mixture of $0.55 \mathrm{M} \mathrm{NH}_{4} \mathrm{H}_{2} \mathrm{PO}_{4}$ ( $\mathrm{pH} 4.0$ ) and acetonitrile $(40: 1, \mathrm{v} / \mathrm{v})$, using a flow rate of $1 \mathrm{ml} \mathrm{min}^{-1}$ at room temperature and detected by UV absorbance at $270 \mathrm{~nm}$. The DNA G + C content of strain BB-My20 ${ }^{\mathrm{T}}$ was $45.1 \mathrm{~mol} \%$, which was a little higher than values reported for members of the genus Salinimicrobium (Ying et al., 2007; Chen et al., 2008; Lim et al., 2008; Nedashkovskaya et al., 2010). These chemotaxonomic data were in agreement with the results of phylogenetic analysis, i.e. that strain $\mathrm{BB}-\mathrm{My} 20^{\mathrm{T}}$ belongs to the genus Salinimicrobium (Ying et al., 2007; Chen et al., 2008; Lim et al., 2008; Nedashkovskaya et al., 2010).

DNA-DNA hybridization was performed fluorometrically by the method of Ezaki et al. (1989) using photobiotinlabelled DNA probes and microdilution wells. Hybridization was performed at $45^{\circ} \mathrm{C}$ with five replications for each sample. The highest and lowest values obtained for each sample were excluded and the means of the remaining three values were quoted as DNA-DNA relatedness values. The mean DNA-DNA relatedness value between strain BBMy $20^{\mathrm{T}}$ and S. catena JCM $14015^{\mathrm{T}}$ was $4.5 \%$, indicating that the two strains are members of different genomic species (Wayne et al., 1987). Strain BB-My $20^{\mathrm{T}}$ could be distinguished from the type strains of the four current members of the genus Salinimicrobium by differences in several phenotypic characteristics, most of which were determined using the same conditions and methods in this study (Table 1). These differences, in combination with phylogenetic and genetic distinctiveness between strain $\mathrm{BB}-\mathrm{My} 20^{\mathrm{T}}$ and the four recognized species of the genus Salinimicrobium, suggest that the isolate represents a novel species of the genus Salinimicrobium (Wayne et al., 1987; Stackebrandt \& Goebel, 1994), for which the name Salinimicrobium gaetbulicola sp. nov. is proposed.

\section{Description of Salinimicrobium gaetbulicola sp. nov.}

Salinimicrobium gaetbulicola [gaet.bu.li.co'la. N.L. n. gaetbulum - $i$ gaetbul, the Korean name for a tidal flat; L. suff. cola (from L. n. incola) a dweller, inhabitant; N.L. fem. n. gaetbulicola a dweller of a tidal flat].

Cells are Gram-stain-negative, non-flagellated, non-gliding, short rod- or rod-shaped, $0.3-0.8 \mu \mathrm{m}$ in diameter and $0.8-5.0 \mu \mathrm{m}$ in length. Colonies on MA are circular, raised, smooth, slightly glistening, vivid yellow in colour and $0.5-$ $1.5 \mathrm{~mm}$ in diameter after incubation for 3 days at $37{ }^{\circ} \mathrm{C}$. Optimal growth temperature is $35-37^{\circ} \mathrm{C}$; growth occurs at 10 and $40{ }^{\circ} \mathrm{C}$, but not at 4 and $45^{\circ} \mathrm{C}$. Optimal $\mathrm{pH}$ for growth is between 7.0 and 7.5; growth occurs at $\mathrm{pH} 5.5$, but not at $\mathrm{pH}$ 5.0. Growth occurs in the presence of $0.5-10.0 \%$ $(\mathrm{w} / \mathrm{v}) \mathrm{NaCl}$ with an optimum of approximately $2.0 \%(\mathrm{w} / \mathrm{v})$ 
$\mathrm{NaCl} . \mathrm{Mg}^{2+}$ ions are required for growth. Anaerobic growth does not occur on MA or on MA supplemented with nitrate. Flexirubin-type pigments are not produced. Catalasepositive and oxidase-negative. Nitrate is not reduced to nitrite. The predominant menaquinone is MK- 6 . The major fatty acids ( $>10 \%$ of the total fatty acids) are iso- $C_{15: 0}$, anteiso- $\mathrm{C}_{15: 0}$ and iso- $\mathrm{C}_{17: 0} 3-\mathrm{OH}$. The major polar lipids are phosphatidylethanolamine and one unidentified lipid. Other phenotypic characteristics are given in Table 1.

The type strain, BB-My20 $0^{\mathrm{T}} \quad\left(=\mathrm{KCTC} 23579^{\mathrm{T}}=\mathrm{CCUG}\right.$ $\left.60898^{\mathrm{T}}\right)$, was isolated from a tidal flat sediment at Beolgyo on the southern coast of Korea. The DNA G + C content of the type strain is $45.1 \mathrm{~mol} \%$.

\section{Acknowledgements}

This work was supported by the Program for Collection, Management and Utilization of Biological Resources (grant M10867010003) and the 21C Frontier Program of Microbial Genomics and Applications (grant M10867010003) from the Ministry of Science \& Technology (MOST) of the Republic of Korea.

\section{References}

Bernardet, J.-F. \& Nakagawa, Y. (2006). An introduction to the family Flavobacteriaceae. In The Prokaryotes: a Handbook on the Biology of Bacteria, 3rd edn, vol. 7, pp. 455-480. Edited by M. Dworkin, S. Falkow, E. Rosenberg, K.-H. Schleifer \& E. Stackebrandt. New York: Springer.

Bowman, J. P. (2000). Description of Cellulophaga algicola sp. nov., isolated from the surfaces of Antarctic algae, and reclassification of Cytophaga uliginosa (ZoBell and Upham 1944) Reichenbach 1989 as Cellulophaga uliginosa comb. nov. Int J Syst Evol Microbiol 50, 1861-1868.

Bruns, A., Rohde, M. \& Berthe-Corti, L. (2001). Muricauda ruestringensis gen. nov., sp. nov., a facultatively anaerobic, appendaged bacterium from German North Sea intertidal sediment. Int J Syst Evol Microbiol 51, 1997-2006.

Chen, Y.-G., Cui, X.-L., Zhang, Y.-Q., Li, W.-J., Wang, Y.-X., Kim, C.-J., Lim, J.-M., Xu, L.-H. \& Jiang, C.-L. (2008). Salinimicrobium terrae sp. nov., isolated from saline soil, and emended description of the genus Salinimicrobium. Int J Syst Evol Microbiol 58, 2501-2504.

Cowan, S. T. \& Steel, K. J. (1965). Manual for the Identification of Medical Bacteria. London: Cambridge University Press.

Ezaki, T., Hashimoto, Y. \& Yabuuchi, E. (1989). Fluorometric deoxyribonucleic acid-deoxyribonucleic acid hybridization in microdilution wells as an alternative to membrane filter hybridization in which radioisotopes are used to determine genetic relatedness among bacterial strains. Int J Syst Bacteriol 39, 224-229.

Komagata, K. \& Suzuki, K. (1987). Lipid and cell-wall analysis in bacterial systematics. Methods Microbiol 19, 161-207.
Lányí, B. (1987). Classical and rapid identification methods for medically important bacteria. Methods Microbiol 19, 1-67.

Leifson, E. (1963). Determination of carbohydrate metabolism of marine bacteria. J Bacteriol 85, 1183-1184.

Lim, J.-M., Jeon, C. O., Lee, S. S., Park, D.-J., Xu, L.-H., Jiang, C.-L. \& Kim, C.-J. (2008). Reclassification of Salegentibacter catena Ying et al. 2007 as Salinimicrobium catena gen. nov., comb. nov. and description of Salinimicrobium xinjiangense sp. nov., a halophilic bacterium isolated from Xinjiang province in China. Int J Syst Evol Microbiol 58, 438-442.

Minnikin, D. E., O'Donnell, A. G., Goodfellow, M., Alderson, G., Athalye, M., Schaal, A. \& Parlett, J. H. (1984). An integrated procedure for the extraction of bacterial isoprenoid quinones and polar lipids. J Microbiol Methods 2, 233-241.

Nedashkovskaya, O. I., Vancanneyt, M., Kim, S. B., Han, J., Zhukova, N. V. \& Shevchenko, L. S. (2010). Salinimicrobium marinum sp. nov., a halophilic bacterium of the family Flavobacteriaceae, and emended descriptions of the genus Salinimicrobium and Salinimicrobium catena. Int J Syst Evol Microbiol 60, 2303-2306.

Sasser, M. (1990). Identification of bacteria by gas chromatography of cellular fatty acids, MIDI Technical Note 101. Newark, DE: MIDI Inc.

Stackebrandt, E. \& Goebel, B. M. (1994). Taxonomic note: a place for DNA-DNA reassociation and 16S rRNA sequence analysis in the present species definition in bacteriology. Int J Syst Bacteriol 44, 846849.

Tamaoka, J. \& Komagata, K. (1984). Determination of DNA base composition by reverse-phase high-performance liquid chromatography. FEMS Microbiol Lett 25, 125-128.

Teather, R. M. \& Wood, P. J. (1982). Use of Congo redpolysaccharide interactions in enumeration and characterization of cellulolytic bacteria from the bovine rumen. Appl Environ Microbiol 43, 777-780.

Wayne, L. G., Brenner, D. J., Colwell, R. R., Grimont, P. A. D., Kandler, O., Krichevsky, M. I., Moore, L. H., Moore, W. E. C., Murray, R. G. E. \& other authors (1987). International Committee on Systematic Bacteriology. Report of the ad hoc committee on reconciliation of approaches to bacterial systematics. Int J Syst Bacteriol 37, 463-464.

Ying, J.-Y., Liu, Z.-P., Wang, B.-J., Dai, X., Yang, S.-S. \& Liu, S.-J. (2007). Salegentibacter catena sp. nov., isolated from sediment of the South China Sea, and emended description of the genus Salegentibacter. Int J Syst Evol Microbiol 57, 219-222.

Yoon, J.-H., Kim, H., Kim, S.-B., Kim, H.-J., Kim, W. Y., Lee, S. T., Goodfellow, M. \& Park, Y.-H. (1996). Identification of Saccharomonospora strains by the use of genomic DNA fragments and rRNA gene probes. Int J Syst Bacteriol 46, 502-505.

Yoon, J.-H., Lee, S. T. \& Park, Y.-H. (1998). Inter- and intraspecific phylogenetic analysis of the genus Nocardioides and related taxa based on 16S rDNA sequences. Int J Syst Bacteriol 48, 187-194.

Yoon, J.-H., Kang, K. H. \& Park, Y.-H. (2003). Psychrobacter jeotgali sp. nov., isolated from jeotgal, a traditional Korean fermented seafood. Int J Syst Evol Microbiol 53, 449-454. 